39 Ehlers S, Gillberg C. The epidemiology of Asperger syndrome. A total population study. J Child Psychol Psychiatry 1993; 34: 1327-50.

40 Wing L. Sex ratios in early childhood autism and related conditions. Psychiatry Res 1981; 5: 129-37.

41 Lutchmaya S, Baron-Cohen S, Raggatt P. Foetal testosterone and eye contact in 12-month-old human infants. Infant Behav Dev 2002; 25: 327-35.

42 Lutchmaya S, Baron-Cohen S, Raggatt P. Foetal testosterone and vocabulary size in 18- and 24-month-old infants. Infant Behav Dev 2002; 24: 418-24.

43 Williams JG, Allison C, Scott FJ, Bolton PF, Baron-Cohen S, Matthews FE, et al. The Childhood Autism Spectrum Test (CAST): sex differences. J Autism Dev Disord 2008; 38: 1731-9.
44 Holliday-Willey L. Pretending to be Normal. Living with Asperger's Syndrome. Jessica Kingsley Publishers, 1999.

45 Kopp S, Gillberg C. Girls with social deficits and learning problems: autism, atypical Asperger syndrome or a variant of these conditions. Eur Child Adolesc Psychiatry 1992; 1: 89-99.

46 Wolff S, McGuire RJ. Schizoid personality in girls: a follow-up study - what are the links with Asperger's syndrome? J Child Psychol Psychiatry 1995; 36 793-817.

47 Allison C, Baron-Cohen S, Wheelwright S, Charman T, Richler J, Pasco G, et al. The Q-CHAT (Quantitative CHecklist for Autism in Toddlers): a normally distributed quantitative measure of autistic traits at 18-24 months of age: preliminary report. J Autism Dev Disord 2008; 38: $1414-25$

\section{0 years ago}

\title{
Themes: part 2
}

\section{Henry R. Rollin}

In this, the second of two contributions, Henry Rollin presents a digest of some of the themes explored in his long-running '100 years ago' series. A full-length article on this topic is available as an online supplement to this item.

\section{Causation of mental illness - proven and alleged}

Masturbation

Psychiatry has its own fashions. A good example was the one rampant at the beginning of the 20th century, when masturbation was considered as the cause of all evils, particularly of the neuroses and even, by others, of the psychoses.

Among those who firmly believed this absurdity was Lord Baden Powell, who founded the Boy Scout movement in 1908, and more surprisingly, by acknowledged leaders of the psychiatric profession, Henry Maudsley and even Sigmund Freud lui-même!

Syphilis proved as the cause of GPI

It is difficult today to appreciate the enormity of the scourge of general paralysis of the insane (GPI) 100 years ago. Statistically, it rated second to alcohol misuse as the cause of admissions to mental hospitals. But whereas, if treated early, alcoholism was recoverable, those suffering from GPI, ab initio, were doomed to die a wretched, lingering death.

But, although syphilis was suspected as the cause of GPI, it could not be confirmed until August von Wasserman (1866-1925), a German bacteriologist, developed a specific blood test (WR) in 1906.

Cannabis including hashish, marijuana, hemp and skunk

For centuries, the addiction to this group of closely allied potent drugs has been common in the Middle East, India and elsewhere - but the hard evidence of its grave consequences was not to be found until the report of Dr John Warnock (Journal of Mental Science, January 1903). He states that for the years 1896-1901, out of 2564 male patients admitted to the Egyptian Asylum at Cairo, 689 were attributed to the use of hashish (27\%). He adds that the addiction is responsible for a substantial amount of crime.

Epilepsy

As recently as 1904, lingering doubts were expressed as to the precise causation of epilepsy. Thus, the Lancet (2 April 1904) published an extract from the Journal of Nervous and Mental Diseases in which Professor Allen M. Starr of New York writes that, 'the prevailing opinion is that epilepsy is usually, if not always, an organic disease.

\section{Neurasthenia}

Professor Charles Dana's long account on neurasthenia in the Boston Medical and Surgical Journal, 1904, to which the Lancet (30 April 1904) devotes a page-long account, is so steeped in heavy sarcasm as to merit its reading in extenso.

Briefly, he alleges that in neurasthenia, 'the psyche has to be hit hard' and that, 'if all that is attributed to neurasthenia is cut away, about one half of the great national malady attributed to it in America is also cut away'.

\section{Doctors v. lawyers}

The antipathy between these two learned professions continues robust. For example, there is the ripe report (Journal of Mental Science, April 1889):

'Mr Justice Field in addition to treating the medical witness with studious rudeness, refused to receive their opinion as to the sanity of the prisoner. "He could no more dive into a man's state of mind than I can", was his final lacerating riposte.

\section{Acknowledgement}

I thank my subeditor-in-chief Dr Anna-Maria Rollin for her skilful work.

P.S. This is the last instalment of the regular column, 100 years ago, although occasional entries will appear in the Journal as extras. 